\title{
QSAR studies of 4,5-dihydro-4-oxo-3H-imidazo[4,5-c]pyridines as potent angiotensin II receptor antagonists by MLR and NLR analysis
}

\author{
Balasubramanian Narasimhan, ${ }^{a *}$ Avinash Dhake, ${ }^{\mathrm{b}}$ and Vishnukant Mourya ${ }^{\mathrm{c}}$ \\ ${ }^{a}$ Faculty of Pharmaceutical Sciences, Guru Jambheshwar University of Science and Technology, \\ Hisar 125001, India \\ ${ }^{b}$ L.B.Rao Institute of Pharmaceutical Education and Research, B.D.Rao College Campus, \\ Khambhat - 388620, India \\ ${ }^{c}$ Govt College of Pharmacy, Osmanpura, Aurangabad 431005, India \\ E-mail:naru2000us@yahoo.com
}

\begin{abstract}
A quantitative structure activity relationship (QSAR) was employed to find out the correlation between the structural properties and angiotensin II receptor antagonistic activity of 4,5-dihydro4-oxo-3H-imidazo[4,5-c]pyridines collected from the literature. The multiple linear regression (MLR) and non-linear regression (NLR) analyses have been carried out to derive best QSAR models. The developed models were cross-validated by the 'leave one out' technique as well as by the calculation of statistical parameters. The present investigation indicated the importance of the quantum chemical descriptor, energy of lowest unoccupied molecular orbital, LUMO and the lipophilic parameter, $\log \mathrm{P}$, in contribution to the studied biological activity. The results of NLR showed that neglecting $\log \mathrm{P}$, based on its low correlation by MLR, as followed by most of the QSAR studies, can lead to fortuitous results and one must perform non-linear regression before coming to a decision on the contribution of the lipophilic parameter, $\log \mathrm{P}$.
\end{abstract}

Keywords: Ang II receptor antagonist, molecular descriptor, MLR, NLR, leave one out method

\section{Introduction}

The vasoactive hormone angiotensin II (ang II) produced by the renin angiotensin system (RAS) is a potent regulator of blood pressure homeostasis, fluid volume and electrolyte balance in mammals ${ }^{1}$. The discovery of losartan and nonpeptide spinacine derived compounds such as PD123, 177 and PD-123, 319, along with peptides such as CGP-42112A, ${ }^{2-4}$ led to confirmation of the existence of ang II receptor heterogeneity followed by the discovery of angiotensin II receptor subtypes $\mathrm{AT}_{1}$ and $\mathrm{AT}_{2}{ }^{5}$. The $\mathrm{AT} 1$ receptor is G-protein coupled ${ }^{6}$ and recognized as 
mediator in regulation of blood pressure ${ }^{7}$. The $\mathrm{AT}_{2}$ receptor has possible roles in renal function, restenosis, growth and wound healing ${ }^{8-11}$. In succession to the development of losartan a number of nonpeptidic heterocyclic ang II antagonists, viz. imidazole biphenyl tetrazoles ${ }^{12}$, fused imidazoles ${ }^{13}$, pyrimidines ${ }^{14}$, benzoyl amino imidazoles ${ }^{15}$, quinazolinone biphenyl tetrazoles, ${ }^{16}$ were developed.

A quantitative structure activity relationship study describes a definite role of a structural feature of a molecule in quantitative terms to the biological activity ${ }^{17}$. In view of the above and in continuation of our QSAR studies in describing chemical structure and biological activity ${ }^{18-24}$, and also for the prediction of basic hydrolytic constant, ${ }^{25}$ in the present work we report a QSAR study on the 4,5-dihydro-4-oxo-3H-imidazo[4,5-c]pyridines reported by Mederski et al. ${ }^{26}$.

Multiple linear regression (MLR) and nonlinear regression (NLR) analyses were used in order to find the relationship between molecular descriptors and ang II receptor antagonistic activity. The descriptors are selected in such a way that some lipophilic, steric, electronic and other characters of these imidazopyridines could be taken into account, since each of them can contribute to the biological activity and give information about the interactions between the compounds and their respective biological receptors.

\section{Results and Discussion}

A set of 27 out of 34, 4,5-dihydro-4-oxo-3 $H$-imidazo[4,5-c]pyridines exhibiting potent angiotensin receptor antagonistic activity was taken from the reported work of Mederski et al. ${ }^{26}$. Seven outliers were removed from the model set and a final set of 27 compounds was selected for MLR and their data along with outliers data are listed in Table 1. In multivariate statistics, it is common to define three types of outliers ${ }^{27}$.

1. $\mathrm{X} / \mathrm{Y}$ relation outliers are substances for which the relationship between the descriptors (X variables) and the dependent variables (Y variables) is not the same as in the (rest of the) training data.

2. X outliers. Briefly, a substance is an X outlier if the molecular descriptors for this substance do not lie in the same range as the (rest of the) training data.

3. Y outliers are only defined for training or test samples. They are substances for which the reference value of response is invalid.

In light of the above guidelines, seven imidazopyridines were considered as outliers because their response values [ang II receptor antagonistic activity] were outside the range in comparison to the other compounds included in the present study. The activity data have been given as $\mathrm{IC}_{50}$ values, where $\mathrm{IC}_{50}$ refers to the experimentally determined molar concentration of the 4,5dihydro-4-oxo-3H-imidazo[4,5-c]pyridines required to inhibit the binding with angiotensin receptor by $50 \%$.

The compounds were divided into training and test sets consisting of 22 and 5 molecules, respectively. The training set has been used for QSAR model development and the test set was 
used to test the ability of developed QSAR model in predicting the angiotensin receptor antagonist activity.

The biological activity values $\left[\mathrm{IC}_{50}(\mathrm{nM})\right]$ reported in the literature were converted to molar units [mol/l] and then further to - log scale and subsequently used as the response variable for the QSAR analysis. The $\mathrm{pIC}_{50}$ values, along with the structure of compounds used in regression analysis as well the outliers in the series, are presented in Table 1.

All calculations were performed by using the molecular package TSAR ${ }^{28}$. In this work, we calculated the following molecular descriptors ${ }^{29-41}$ (Table 2) for imidazopyridines and the values of the selected descriptors used in the development of MLR model are presented in Table 3.

The correlation matrix constructed to find out the relationship between molecular descriptors and biological activity, as well as the interrelationship among the parameters, is presented in Table 4. From the correlation matrix it was observed that $\mathrm{pIC}_{50}\left(\mathrm{AT}_{1}\right)$ was highly correlated with $\log P, r=-0.892$, whereas in all other cases $r>0.6$. In the first step, the statistical method of stepwise multiple regression procedure, based on the forward selection method, was applied for variable selection with the aim to obtain the best regression equation (in such a way that variables that show little increment or are redundant in the explanation of the dependent variable were not included).

By following the above facts, the MLR analysis yielded the best mono-parametric model with $\log \mathrm{P}$. The model was given as follows.

Table 1. Chemical and biological data of 4,5-dihydro-4-oxo-3H-imidazo[4,5-c]pyridines

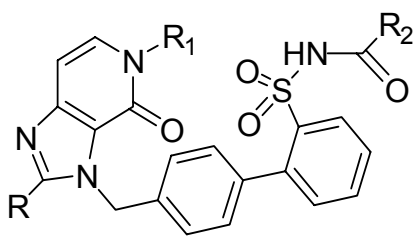

[Cmpd. 1 to 4, 28-30]

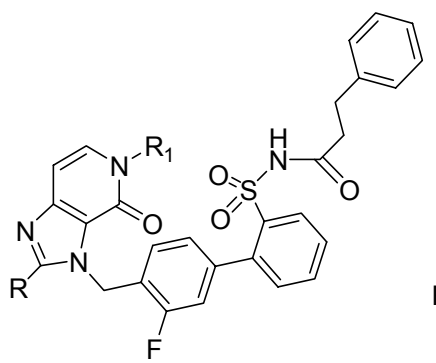

[Cmpd. 5 to 9,23-25, 31-33] [Cmpd. 10 to 22, 26, 27, 34]

\begin{tabular}{|c|c|c|c|c|c|}
\hline Cmpd. & $\mathrm{R}$ & $\mathrm{R}_{1}$ & $\mathrm{R}_{2}$ & $\mathrm{pIC}_{50}\left(\mathrm{AT}_{1}\right)^{*}$ & $\mathrm{pIC}_{50}\left(\mathrm{AT}_{2}\right)^{*}$ \\
\hline \multicolumn{6}{|c|}{ Training set } \\
\hline 1 & $\mathrm{Bu}$ & $\mathrm{CH}_{2} \mathrm{Ph}$ & $\mathrm{OBu}$ & 6.47 & 5.87 \\
\hline 2 & $\mathrm{Bu}$ & $\mathrm{CH}_{2} \mathrm{CONPh}_{2}$ & $\mathrm{OBu}$ & 6.40 & 5.24 \\
\hline 3 & $\mathrm{Bu}$ & $\mathrm{CH}_{2} \mathrm{CONMe}_{2}$ & $\left(\mathrm{CH}_{2}\right)_{2} \mathrm{Ph}$ & 7.33 & 5.68 \\
\hline 4 & $\mathrm{Bu}$ & $\mathrm{CH}_{2} \mathrm{CONMe}_{2}$ & $\mathrm{CH}_{2} i-\mathrm{Pr}$ & 7.38 & 4.89 \\
\hline 5 & $\mathrm{Bu}$ & $\mathrm{CH}_{2} \mathrm{CONMe}_{2}$ & - & 7.51 & 7.03 \\
\hline 6 & $\operatorname{Pr}$ & $\mathrm{CH}_{2} \mathrm{CONMe}_{2}$ & - & 7.57 & 7.19 \\
\hline 7 & $\mathrm{Bu}$ & $\mathrm{CH}_{2} \mathrm{Ph}$ & - & 6.46 & 6.78 \\
\hline 8 & $\mathrm{Bu}$ & $\mathrm{CH}_{2} \mathrm{COPh}$ & - & 6.52 & 6.62 \\
\hline
\end{tabular}




\begin{tabular}{|c|c|c|c|c|c|}
\hline 9 & $\mathrm{Bu}$ & $\mathrm{CH}_{2} \mathrm{COOEt}$ & - & 7.36 & 7.05 \\
\hline 10 & $\mathrm{Bu}$ & $\mathrm{NHCH}_{2} i-\mathrm{Pr}$ & $\mathrm{CH}_{2}$ & 7.24 & 7.48 \\
\hline 11 & $\mathrm{Bu}$ & $\mathrm{NH} t-\mathrm{Bu}$ & $\mathrm{CH}_{2}$ & 7.41 & 7.52 \\
\hline 12 & $\mathrm{Bu}$ & $\mathrm{NHCH}_{2} \mathrm{Ph}$ & $\mathrm{CH}_{2}$ & 6.94 & 7.15 \\
\hline 13 & $\mathrm{Bu}$ & Pip $^{\mathrm{C}}$ & $\mathrm{CH}_{2}$ & 7.40 & 7.42 \\
\hline 14 & $\mathrm{Bu}$ & $\mathrm{NH}_{2}$ & $\mathrm{CH}_{2}$ & 7.54 & 6.89 \\
\hline 15 & $\operatorname{Pr}$ & $\mathrm{NH} n-\mathrm{Pn}$ & $\mathrm{CH}_{2}$ & 7.06 & 7.08 \\
\hline 16 & $\operatorname{Pr}$ & $\mathrm{NH} n-\mathrm{Bu}$ & $\mathrm{CH}_{2}$ & 7.34 & 7.25 \\
\hline 17 & $\operatorname{Pr}$ & $\mathrm{NH} n-\mathrm{Pr}$ & $\mathrm{CH}_{2}$ & 7.57 & 7.74 \\
\hline 18 & $\operatorname{Pr}$ & $\mathrm{NH}\left(\mathrm{CH}_{2}\right)_{2} i-\mathrm{Pr}$ & $\mathrm{CH}_{2}$ & 7.20 & 7.19 \\
\hline 19 & $\operatorname{Pr}$ & $\mathrm{NH} t-\mathrm{Bu}$ & $\mathrm{CH}_{2}$ & 7.43 & 7.68 \\
\hline 20 & $\operatorname{Pr}$ & Pip $^{\mathrm{C}}$ & $\mathrm{CH}_{2}$ & 7.44 & 7.59 \\
\hline 21 & $\mathrm{Bu}$ & $\operatorname{Pip}^{\mathrm{C}}$ & $\mathrm{O}$ & 7.33 & 7.46 \\
\hline 22 & $\operatorname{Pr}$ & $\mathrm{Pip}^{\mathrm{C}}$ & $\mathrm{O}$ & 7.54 & 7.38 \\
\hline \multicolumn{6}{|c|}{ Test set } \\
\hline 23 & Et & $\mathrm{CH}_{2} \mathrm{CONMe}_{2}$ & - & 7.42 & 6.74 \\
\hline 24 & $\mathrm{Bu}$ & $\mathrm{CH}_{2} \mathrm{CH}_{2} \mathrm{COPh}$ & - & 6.41 & 6.59 \\
\hline 25 & $\mathrm{Bu}$ & $\mathrm{CH}_{2} \mathrm{CO} n-\mathrm{Bu}$ & - & 7.08 & 6.34 \\
\hline 26 & $\mathrm{Bu}$ & $\mathrm{NH} n-\mathrm{Pr}$ & $\mathrm{CH}_{2}$ & 7.44 & 7.52 \\
\hline 27 & $\operatorname{Pr}$ & $\mathrm{NH}\left(\mathrm{CH}_{2}\right)_{3} i-\mathrm{Pr}$ & $\mathrm{CH}_{2}$ & 6.84 & 6.74 \\
\hline \multicolumn{6}{|c|}{ Outliers } \\
\hline 28 & $\mathrm{Bu}$ & $\mathrm{CH}_{2} \mathrm{CONMe}_{2}$ & $\mathrm{OBu}$ & 7.44 & 9.33 \\
\hline 29 & $\mathrm{Bu}$ & $\mathrm{CH}_{2} \mathrm{CONMe}_{2}$ & $\mathrm{Ph}$ & 7.26 & 9.97 \\
\hline 30 & $\mathrm{Bu}$ & $\mathrm{CH}_{2} \mathrm{CONMe}_{2}$ & $\mathrm{CH}_{2}-\mathrm{t}-\mathrm{Bu}$ & 7.79 & 10.43 \\
\hline 31 & $\mathrm{Bu}$ & $\mathrm{CH}_{2} \mathrm{COMe}$ & - & 8.75 & 8.47 \\
\hline 32 & $\mathrm{Bu}$ & $\mathrm{CH}_{2} \mathrm{CO}-\mathrm{t}-\mathrm{Bu}$ & - & 8.07 & 8.34 \\
\hline 33 & $\mathrm{Bu}$ & $\mathrm{CH}_{2} \mathrm{COOH}$ & - & 8.34 & 9.13 \\
\hline 34 & $\mathrm{Bu}$ & $\mathrm{NEt}_{2}$ & $\mathrm{CH}_{2}$ & 7.53 & 7.67 \\
\hline
\end{tabular}

${ }_{-}-\mathrm{AT}_{1}$ and $\mathrm{AT}_{2}$ are $\mathrm{IC}_{50}$ values in $\mathrm{mol} / \mathrm{l}$.

\section{QSAR model for $\mathrm{AT}_{1}$ antagonistic activity}

$$
\begin{aligned}
& \mathrm{pIC}_{50}\left(\mathrm{AT}_{1}\right)=-0.357( \pm 0.040) \log \mathrm{P}+9.404( \pm 0.252) \\
& \mathrm{n}=22 \quad \mathrm{r}=-0.892 \quad \mathrm{q}^{2}=0.731 \quad \mathrm{~F}=77.97 \quad \mathrm{~s}=0.180 \quad(\mathrm{p}<0.001)
\end{aligned}
$$

Eq-1 shows inverse relationship between activity and $\log \mathrm{P}$, but the trends shown by the compounds were different. Compound 2, which has the $\log \mathrm{P}$ value of 8.23 has a lesser activity than many compounds in Table 1. Similarly, compound 4 with a $\operatorname{low} \log P$ value of 4.32 shows the activity, $-\log \mathrm{AT}_{1}=7.38$, which was higher than the activity values of many compounds which have $\log \mathrm{P}$ values higher than compound 4. 
This indicated that there might exist a nonlinear relationship of the descriptor $\log \mathrm{P}$ with the $\mathrm{AT}_{1}$ receptor antagonistic activity. This was evidenced by the QSAR model (Eq. 2) obtained by non-linear regression having more statistical significance than the one obtained by MLR.

Table 2. Molecular descriptors calculated for QSAR study

\begin{tabular}{lll}
\hline S.No. & \multicolumn{1}{c}{ QSAR descriptor } & \multicolumn{1}{c}{ Type } \\
\hline 1 & Log P & Lipophilic \\
2 & Total lipole & Lipophilic \\
3 & Lipole components & Lipophilic \\
4 & Energy of highest occupied molecular orbital (HOMO) & Quantum chemical \\
5 & Energy of lowest unoccupied molecular orbital (LUMO) & Quantum chemical \\
6 & Steric energy (SE) & Quantum chemical \\
7 & Conformational minimum energy $(\mathrm{CME})$ & Quantum chemical \\
8 & Zero order molecular connectivity indices $\left({ }^{0} \chi\right)$ & Topological \\
9 & First order molecular connectivity indices $\left({ }^{1} \chi\right)$ & Topological \\
10 & Second order molecular connectivity indices $\left({ }^{2} \chi\right)$ & Topological \\
11 & Third order molecular connectivity indices $\left({ }^{3} \chi\right)$ & Topological \\
12 & Valence zero order molecular connectivity indices $\left({ }^{0} \chi^{\mathrm{v}}\right)$ & Topological \\
13 & Valence first order molecular connectivity indices $\left({ }^{1} \chi^{\mathrm{v}}\right)$ & Topological \\
14 & Valence second order molecular connectivity indices $\left({ }^{2} \chi^{\mathrm{v}}\right)$ & Topological \\
15 & Valence third order molecular connectivity indices $\left({ }^{3} \chi^{\mathrm{v}}\right)$ & Topological \\
16 & Kier's zero order shape indice $\left(\kappa_{0}\right)$ & Topological \\
17 & Kier's first order shape indice $\left(\kappa_{1}\right)$ & Topological \\
18 & Kier's second order shape indice $\left(\kappa_{2}\right)$ & Topological \\
19 & Kier's third order shape indice $\left(\kappa_{3}\right)$ & Topological \\
20 & Ionization potential & Electronic \\
21 & Dipole moment $(\mu)$ & Electronic \\
22 & Dipole Moment $-\mathrm{X}$ Axis $(\mathrm{DX})$ & Electronic \\
23 & Dipole Moment $-Y$ Axis $(\mathrm{DY})$ & Electronic \\
24 & Dipole Moment $-Y$ Axis $(\mathrm{DZ})$ & Electronic \\
25 & Molar refractivity $($ MR) & Polarizability \\
26 & Solvent accessible surface area $(\mathrm{SASA})$ & Polarizability \\
\hline
\end{tabular}


Table 3. Values of molecular descriptors used in MLR analysis

\begin{tabular}{|c|c|c|c|c|c|c|c|c|c|}
\hline Cmpd. & ${ }^{0} \chi$ & $\log \mathrm{P}$ & HOMO & MR & $\mathrm{SE}$ & LUMO & ${ }^{1} \chi^{v}$ & $\kappa^{1}$ & $\mu$ \\
\hline \multicolumn{10}{|c|}{ Training set } \\
\hline 1 & 31.81 & 7.48 & -8.55 & 174.18 & -16.56 & -0.97 & 16.79 & 36.29 & 5.87 \\
\hline 2 & 38.08 & 8.23 & -8.56 & 206.82 & 9.38 & -0.97 & 19.58 & 43.58 & 3.68 \\
\hline 3 & 33.55 & 5.28 & -8.66 & 181.09 & -5.64 & -0.93 & 17.12 & 38.24 & 4.09 \\
\hline 4 & 31.31 & 4.39 & -8.69 & 165.54 & 5.59 & -0.89 & 15.92 & 35.85 & 4.43 \\
\hline 5 & 34.42 & 5.42 & -8.55 & 181.31 & -13.14 & -1.01 & 17.23 & 39.21 & 5.54 \\
\hline 6 & 33.72 & 5.02 & -8.71 & 176.70 & -14.04 & -1.01 & 16.73 & 38.24 & 6.56 \\
\hline 7 & 34.38 & 8.03 & -8.54 & 188.22 & -27.12 & -0.97 & 17.81 & 38.72 & 8.05 \\
\hline 8 & 35.96 & 7.31 & -8.52 & 193.51 & -10.58 & -0.96 & 18.27 & 40.66 & 7.60 \\
\hline 9 & 34.26 & 6.17 & -8.65 & 179.21 & -7.91 & -1.00 & 17.31 & 39.21 & 7.54 \\
\hline 10 & 35.84 & 6.39 & -8.65 & 190.15 & -21.14 & -0.98 & 18.27 & 41.17 & 6.46 \\
\hline 11 & 36.05 & 6.01 & -8.77 & 190.21 & -18.07 & -1.01 & 18.11 & 41.17 & 5.40 \\
\hline 12 & 37.37 & 6.95 & -8.73 & 201.02 & -30.75 & -1.03 & 18.98 & 42.60 & 9.03 \\
\hline 13 & 35.96 & 6.14 & -8.60 & 193.45 & -0.87 & -1.04 & 18.96 & 40.66 & 6.36 \\
\hline 14 & 32.85 & 4.93 & -8.90 & 171.51 & -21.38 & -1.03 & 16.40 & 37.26 & 6.42 \\
\hline 15 & 35.68 & 6.38 & -8.74 & 190.28 & -14.99 & -1.03 & 18.42 & 41.17 & 5.81 \\
\hline 16 & 34.97 & 5.98 & -8.75 & 185.68 & -20.91 & -1.03 & 17.92 & 40.19 & 5.31 \\
\hline 17 & 34.26 & 5.59 & -8.69 & 181.08 & -21.63 & -1.01 & 17.42 & 39.21 & 5.79 \\
\hline 18 & 35.84 & 6.31 & -8.64 & 190.23 & -15.41 & -1.00 & 18.27 & 41.17 & 5.67 \\
\hline 19 & 35.35 & 5.61 & -8.92 & 185.61 & -17.96 & -1.06 & 17.61 & 40.19 & 5.85 \\
\hline 20 & 35.25 & 5.75 & -8.61 & 188.85 & -1.56 & -1.03 & 18.46 & 39.69 & 6.58 \\
\hline 21 & 35.96 & 6.30 & -8.61 & 190.36 & -10.01 & -1.08 & 18.60 & 40.66 & 7.74 \\
\hline 22 & 35.25 & 5.91 & -8.62 & 185.76 & -9.81 & -1.07 & 18.10 & 39.69 & 8.04 \\
\hline \multicolumn{10}{|l|}{ Test set } \\
\hline 23 & 33.01 & 4.63 & -8.69 & 172.10 & -13.13 & -1.01 & 16.23 & 37.26 & 5.65 \\
\hline 24 & 36.67 & 7.50 & -8.62 & 198.21 & -20.87 & -1.00 & 18.77 & 41.63 & 9.78 \\
\hline 25 & 34.97 & 7.76 & -8.66 & 187.07 & -7.36 & -1.00 & 18.17 & 40.19 & 8.00 \\
\hline 26 & 34.97 & 5.98 & -8.65 & 185.68 & -20.81 & -0.99 & 17.92 & 40.19 & 6.29 \\
\hline 27 & 36.55 & 6.71 & -8.76 & 194.83 & -18.78 & -1.03 & 18.77 & 42.15 & 5.20 \\
\hline \multicolumn{10}{|l|}{ Outliers } \\
\hline 28 & 31.85 & 4.41 & -8.58 & 168.45 & -18.30 & -1.00 & 16.32 & 36.83 & 6.46 \\
\hline 29 & 32.14 & 4.49 & -8.53 & 173.12 & 5.82 & -0.98 & 16.28 & 36.28 & 8.32 \\
\hline 30 & 32.23 & 4.36 & -8.51 & 171.20 & -20.37 & -1.01 & 16.33 & 36.83 & 7.38 \\
\hline 31 & 32.85 & 5.88 & -8.50 & 174.43 & -22.86 & -0.99 & 16.73 & 37.26 & 1.85 \\
\hline 32 & 35.35 & 7.73 & -8.66 & 188.13 & -20.62 & -0.66 & 17.98 & 40.19 & 4.44 \\
\hline 33 & 32.85 & 5.33 & -8.65 & 170.87 & -35.08 & -1.01 & 16.45 & 37.26 & 1.77 \\
\hline 34 & 34.26 & 6.82 & -8.46 & 187.11 & -15.27 & -0.99 & 18.03 & 39.21 & 3.27 \\
\hline
\end{tabular}


Table 4. Correlation matrix constructed to measure the interrelationship among the parameters

\begin{tabular}{|c|c|c|c|c|c|c|c|c|c|}
\hline & $\begin{array}{l}\mathrm{pIC}_{50} \\
\left(\mathrm{AT}_{1}\right)^{0} \chi\end{array}$ & $\log \mathrm{P}$ & HOMO & $\mathrm{MR}$ & $\mathrm{SE}$ & $\operatorname{LUMO}^{1} \chi^{\mathrm{v}}$ & $\kappa_{1}$ & $(\log P)^{2}$ & $\begin{array}{l}\mathrm{pIC}_{50} \\
\left(\mathrm{AT}_{2}\right)\end{array}$ \\
\hline $\mathrm{pIC}_{50}$ & & & & & & & & -0.917 & \\
\hline$\left(\mathrm{AT}_{1}\right)$ & 1.000 & & & & & & & $(-0.202 * *)$ & 1.000 \\
\hline${ }^{0} \chi$ & -0.2181 .000 & & & & & & & 0.470 & 0.362 \\
\hline $\log \mathrm{P}$ & -0.8920 .510 & 1.000 & & & & & & 0.996 & -0.130 \\
\hline HOMO & -0.5120 .104 & 0.534 & 1.000 & & & & & 0.540 & -0.283 \\
\hline MR & -0.4280 .963 & 0.674 & 0.257 & 1.000 & & & & 0.643 & 0.209 \\
\hline SE & $0.001-0.020$ & -0.108 & 0.345 & 0.009 & 1.000 & & & -0.073 & -0.531 \\
\hline LUMO & $-0.390-0.429$ & 0.048 & 0.315 & -0.289 & 0.305 & 1.000 & & 0.106 & 0.797 \\
\hline${ }^{1} \chi^{v}$ & -0.3320 .943 & 0.622 & 0.282 & 0.969 & 0.076 & -0.3961 .000 & & 0.582 & 0.289 \\
\hline$\kappa^{1}$ & -0.2160 .988 & 0.496 & 0.063 & 0.945 & -0.033 & $3-0.3800 .922$ & 21.000 & 0.455 & 0.328 \\
\hline$\mu$ & -0.0630 .207 & 0.243 & 0.112 & 0.179 & -0.494 & $4-0.4650 .209$ & 0.1241 .000 & 0.206 & 0.516 \\
\hline
\end{tabular}

MLR partial correlation of $(\log \mathrm{P})^{2}$ with $\mathrm{pIC}_{50}\left(\mathrm{AT}_{2}\right)$

QSAR model for $\mathrm{AT}_{1}$ antagonistic activity

$\mathrm{pIC}_{50}\left(\mathrm{AT}_{1}\right)=0.978( \pm 0.321) \log \mathrm{P}-0.104( \pm 0.025) \log \mathrm{P}^{2}+5.234( \pm 1.013)$

$\mathrm{n}=22 \quad \mathrm{r}=0.945 \quad \mathrm{q}^{2}=0.882 \quad \mathrm{~F}=79.94 \quad \mathrm{~s}=0.133 \quad(\mathrm{p}<0.001)$

The sample size and the 'Rule of Thumb' allowed us to go for the development of multiparametric models. Among the multi-parametric models, the bi-parametric models showed significant increase in r-value. The addition of the molecular descriptor, LUMO to $\log \mathrm{P}$ significantly increased the correlation coefficient (Eq. 3).

\section{QSAR model for $\mathrm{AT}_{1}$ antagonistic activity}

$$
\mathrm{pIC}_{50}\left(\mathrm{AT}_{1}\right)=-0.351( \pm 0.340) \log \mathrm{P}-3.021( \pm 0.136) \mathrm{LUMO}+6.327( \pm 7.201)(3)
$$

$\mathrm{n}=22 \quad \mathrm{r}=0.958 \quad \mathrm{q}^{2}=0.888 \quad \mathrm{~F}=106.13 \mathrm{~s}=0.117 \quad(\mathrm{p}<0.001)$

Further, one should not forget to note that the interrelationship between $\log \mathrm{P}$ and LUMO was very low ( $r=0.048$ for $\log \mathrm{P}$ with LUMO, Table 4$)$ in comparison to the other descriptors, which also favors the combination of these descriptors. Similarly, the addition of valence first order molecular connectivity to $\log \mathrm{P}$ also improved the r-value (Eq. 4).

The electronic parameter LUMO, which denotes energy of the lowest unoccupied molecular orbital, directly related to the electron affinity and characterizes the susceptibility of the molecule towards attack by nucleophiles. An electron deficiency in the lowest unoccupied molecular orbital (LUMO), shows its low energy and low electron density, which gives a molecule a favorable condition for the acceptance of an electron ${ }^{42-43}$. The trend in the imidazopyridines was such that the lower the LUMO energy of the molecule, the higher the activity of the molecule, as 
evidenced by the LUMO values (Table 3) and angiotensin receptor antagonistic activity values of imidazopyridines (Table 1).

QSAR model for $\mathrm{AT}_{\mathbf{1}}$ antagonistic activity

$$
\begin{aligned}
& \mathrm{pIC}_{50}\left(\mathrm{AT}_{1}\right)=-0.447( \pm 0.434) \log \mathrm{P}+0.156( \pm 0.141){ }^{1} \chi^{\mathrm{v}}-7.170( \pm 7.201)(4) \\
& \mathrm{n}=22 \quad \mathrm{r}=0.936 \quad \mathrm{q}^{2}=0.821 \quad \mathrm{~F}=67.50 \quad \mathrm{~s}=0.143 \quad(\mathrm{p}<0.001)
\end{aligned}
$$

In order to confirm our results we have estimated the ang II receptor antagonistic activity $\mathrm{pIC}_{50}\left(\mathrm{AT}_{1}\right)$ of test and training sets using the model expressed by Eq. 3 and compared them with the observed values. The data presented in Table 5 show that the observed and predicted activities are very close each other. This was further supported by the plot of MLR predicted $\mathrm{pIC}_{50}\left(\mathrm{AT}_{1}\right)$ values against the observed $\mathrm{pIC}_{50}\left(\mathrm{AT}_{1}\right)$ values (Figure 1$)$ and the lowest values of the statistical parameters PE, LSE, LOF and SEP estimated in Table 6 are also in favor of the biparametric model containing log P and LUMO.

Table 5. Observed and predicted angiotensin II receptor antagonistic activity of substituted imidazopyridines using the best MLR models

\begin{tabular}{ccccccc}
\hline \multirow{2}{*}{ Comp. } & \multicolumn{3}{c}{ pIC50(AT1) by Eq. 3 } & \multicolumn{3}{c}{ pIC50(AT2) by Eq. 6 } \\
\cline { 2 - 7 } & Obs. & Calc. & Resi. & Obs. & Calc. & Resi. \\
\hline Training set & & & & & & \\
1 & 6.47 & 6.63 & -0.16 & 5.87 & 6.58 & -0.71 \\
2 & 6.40 & 6.37 & 0.03 & 5.24 & 5.92 & -0.68 \\
3 & 7.33 & 7.28 & 0.05 & 5.68 & 5.81 & -0.13 \\
4 & 7.38 & 7.48 & -0.10 & 4.89 & 5.03 & -0.14 \\
5 & 7.51 & 7.48 & 0.03 & 7.03 & 6.98 & 0.05 \\
6 & 7.57 & 7.62 & -0.05 & 7.19 & 7.01 & 0.18 \\
7 & 6.46 & 6.44 & 0.02 & 6.78 & 6.84 & -0.06 \\
8 & 6.52 & 6.66 & -0.14 & 6.62 & 6.30 & 0.32 \\
9 & 7.36 & 7.18 & 0.18 & 7.05 & 6.73 & 0.32 \\
10 & 7.24 & 7.05 & 0.19 & 7.48 & 6.82 & 0.66 \\
11 & 7.41 & 7.27 & 0.14 & 7.52 & 7.11 & 0.41 \\
12 & 6.94 & 7.00 & -0.06 & 7.15 & 7.67 & -0.52 \\
13 & 7.40 & 7.32 & 0.08 & 7.42 & 7.05 & 0.37 \\
14 & 7.54 & 7.71 & -0.17 & 6.89 & 7.44 & -0.55 \\
15 & 7.06 & 7.20 & -0.14 & 7.08 & 7.28 & -0.20 \\
16 & 7.34 & 7.34 & 0.00 & 7.25 & 7.43 & -0.18 \\
17 & 7.57 & 7.42 & 0.15 & 7.74 & 7.20 & 0.54 \\
18 & 7.20 & 7.14 & 0.06 & 7.19 & 6.92 & 0.27 \\
19 & 7.43 & 7.56 & -0.13 & 7.68 & 7.72 & -0.04 \\
20 & 7.44 & 7.42 & 0.02 & 7.59 & 6.94 & 0.65 \\
21 & 7.33 & 7.38 & -0.05 & 7.46 & 7.77 & -0.31 \\
\hline & & & & & &
\end{tabular}




\begin{tabular}{ccccccc}
\hline 22 & 7.54 & 7.49 & 0.05 & 7.38 & 7.64 & -0.26 \\
$\begin{array}{c}\text { Test set } \\
23\end{array}$ & 7.42 & 7.75 & -0.33 & 6.74 & 6.98 & -0.24 \\
24 & 6.41 & 6.72 & -0.31 & 6.59 & 7.05 & -0.46 \\
25 & 7.08 & 6.62 & 0.46 & 6.34 & 6.71 & -0.37 \\
26 & 7.44 & 7.22 & 0.22 & 7.52 & 6.93 & 0.59 \\
27 & 6.84 & 7.08 & -0.24 & 6.74 & 7.37 & -0.63 \\
\hline
\end{tabular}

Table 6. PE, LSE, LOF and SEP values calculated for angiotensin II receptor antagonistic activity of substituted imidazopyridines using the best MLR models

\begin{tabular}{llllll}
\hline Model & $\begin{array}{l}\text { Molecular } \\
\text { Descriptor }\end{array}$ & PE & LSE & LOF & SEP \\
\hline For $\mathrm{AT}_{1}$ & & & & & \\
1 & Log P & 0.029 & 0.648 & 0.868 & 0.037 \\
2 & Log P* & 0.015 & 0.337 & 0.451 & 0.026 \\
3 & Log P, LUMO & 0.012 & 0.261 & 0.390 & 0.023 \\
4 & Log P, ${ }^{1} \chi^{\mathrm{v}}$ & 0.018 & 0.392 & 0.585 & 0.028 \\
ForAT $_{2}$ & & & & & \\
1 & LUMO & 0.051 & 4.802 & 5.471 & 0.099 \\
2 & Log P & 0.139 & 13.182 & 17.67 & 0.165 \\
3 & Log P* & 0.055 & 5.106 & 6.845 & 0.103 \\
4 & LUMO, SE & 0.039 & 3.600 & 5.381 & 0.086 \\
5 & LUMO, $\mu$ & 0.048 & 4.448 & 6.648 & 0.096 \\
\hline
\end{tabular}

*Models obtained by non-linear regression

This first order valence connectivity index $\left({ }^{1} \chi^{v}\right)$ signifies the degree of branching, connectivity of atoms, and the unsaturation in the molecule ${ }^{19}$, which accounts for the variation in the activity of imdazopyridines. 


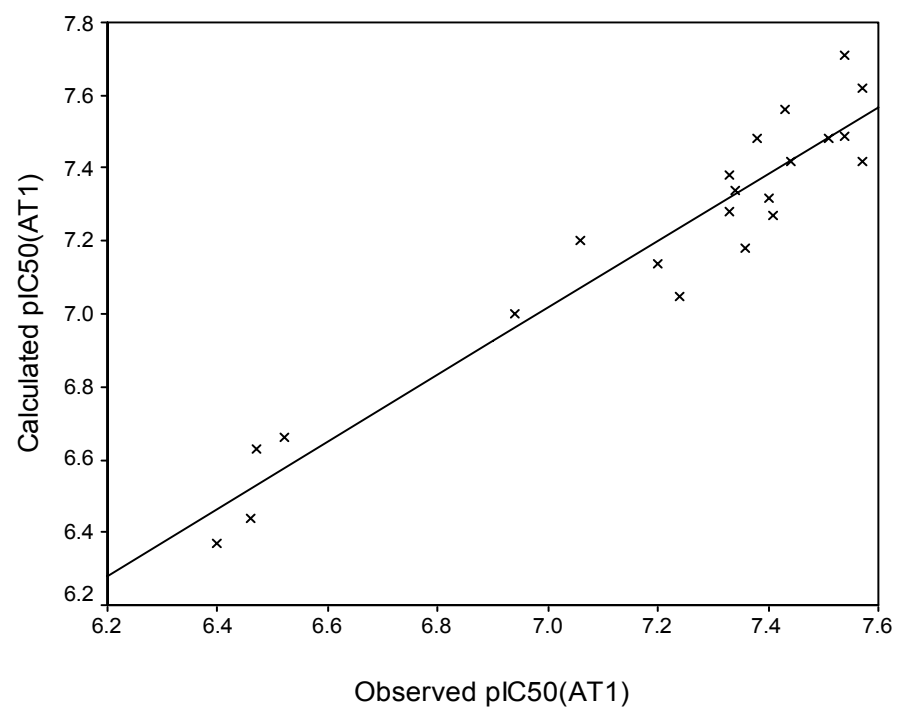

Figure 1. Plot of predicted pIC50(AT $\left.\mathrm{A}_{1}\right)$ activity values $\mathrm{Vs}$ the experimental pIC50(AT $)_{1}$ values for the MLR model by Eq. 3.

To investigate the existence of systemic error in developing the MLR model, the residuals of MLR predicted values of pIC50(AT $)$ were plotted against the experimental values in Figure 2. The propagation of residuals on both the sides of zero indicates that there is no systemic error in the development of the MLR model.

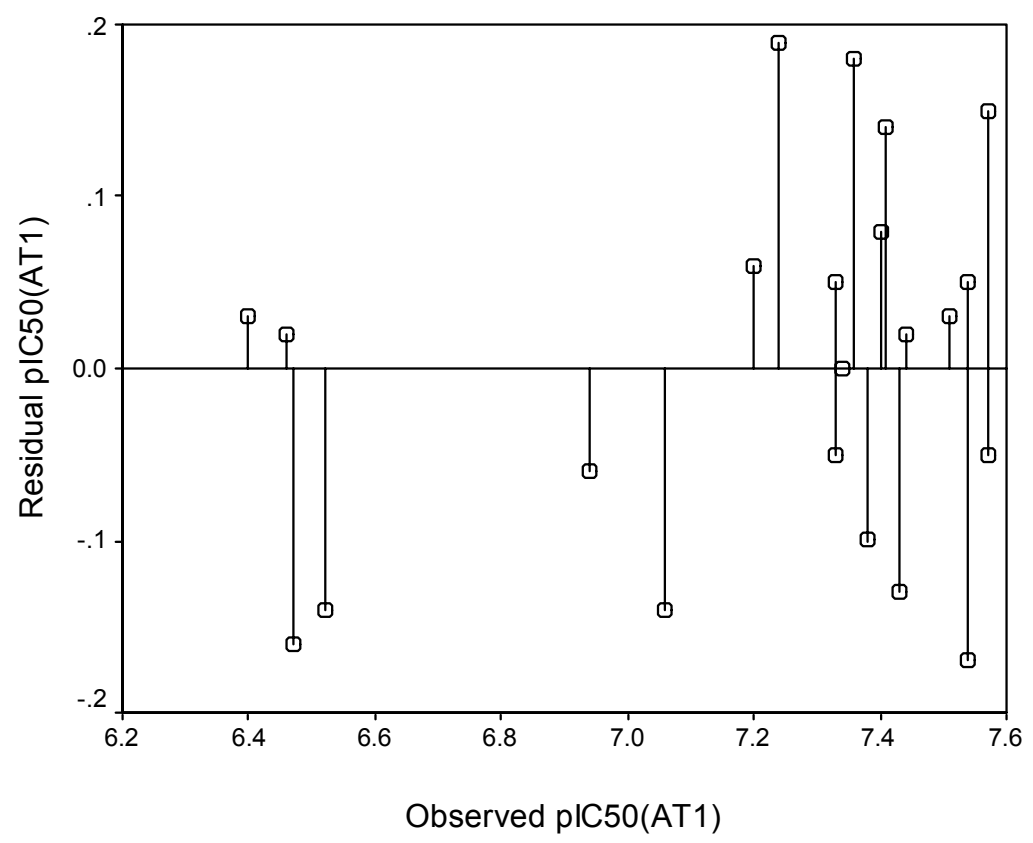

Figure 2. Plot of residuals against the experimental $\mathrm{pIC}_{50}\left(\mathrm{AT}_{1}\right)$ values for the developed MLR model by Eq.3. 
The correlation matrix indicates that, in the case of $\mathrm{AT}_{2}$ antagonistic activity, the molecular descriptor, LUMO is highly correlated with $\mathrm{pIC}_{50}\left(\mathrm{AT}_{2}\right)(\mathrm{r}=0.797$, Table 4). The regression parameters of LUMO show that it was the only quantum chemical descriptor capable of giving a statistically significant mono-parametric model. This model was found as below:

QSAR model for $\mathbf{A T}_{2}$ antagonistic activity

$$
\begin{array}{lll}
\mathrm{pIC}_{50}\left(\mathrm{AT}_{2}\right)=-14.033 & ( \pm 0.631) \text { LUMO }-7.185( \pm 6.917) \\
\mathrm{n}=22 & \mathrm{r}=0.797 \quad \mathrm{q}^{2}=0.557 \quad \mathrm{~F}=34.89 \quad \mathrm{~s}=0.490
\end{array}
$$

This shows that $\mathrm{AT}_{2}$ receptor antagonistic activities of imidazopyridines were inversely proportional to the magnitude of LUMO. Once again, following the 'Rule of Thumb' we have ultimately made the multi-parametric model. The bi-parametric model containing LUMO, SE and LUMO, $\mu$ resulted in the best biparametric models (Eq. 6-Eq. 7).

\section{QSAR model for $\mathrm{AT}_{\mathbf{2}}$ antagonistic activity}

$$
\begin{aligned}
& \mathrm{pIC}_{50}\left(\mathrm{AT}_{2}\right)=-12.329( \pm 0.554) \text { LUMO }-0.025( \pm 0.251) \mathrm{SE}-5.799( \pm 6.917)(6) \\
& \mathrm{n}=22 \quad \mathrm{r}=0.852 \quad \mathrm{q}^{2}=0.621 \quad \mathrm{~F}=25.28 \quad \mathrm{~s}=0.435 \\
& \operatorname{pIC}_{50}\left(\mathrm{AT}_{2}\right)=-12.517( \pm 0.563) \text { LUMO }+0.109( \pm 0.146) \mu-6.346( \pm 6.917)(7) \\
& \mathrm{n}=22 \quad \mathrm{r}=0.814 \quad \mathrm{q}^{2}=0.521 \quad \mathrm{~F}=18.64 \quad \mathrm{~s}=0.483
\end{aligned}
$$

Furthermore, the comparison of experimental and predicted values of test and training sets (Table 5, Figure 3) and the lowest values of the statistical parameters PE, LSE, LOF, SEP are in favor of the proposed model given by Eq. 6. Similarly, the propagation of residuals on both sides of zero in Figure 4 as observed in case of $\mathrm{AT}_{1}$ also favors the developed bi-parametric model.

The steric energy of the molecule represents the conformation minimum energy of the molecule. The negative coefficient of SE in Eq.6 indicated that for a compound to be more active, it should be in the minimum energy conformation so that it can fit into the receptor effectively. The SE values of imidazopyridines in Table 3 reflect the above trend that the compounds with minimum steric energy were found to be more active than the others, which have high steric energy values. Further, it is important to note that the correlation between SE and LUMO is also very low $(r=0.305$, Table 4$)$ which also justifies the combination of these parameters to develop a better biparametric QSAR model.

It is noteworthy that the correlation of $\log \mathrm{P}$ with $\mathrm{AT}_{2}$ antagonistic activity was found to be very low, $(r=-0.130$, Table 4$)$. The MLR model expressed by Eq. 8 obtained with $\log \mathrm{P}$ also reflects the same fact. 


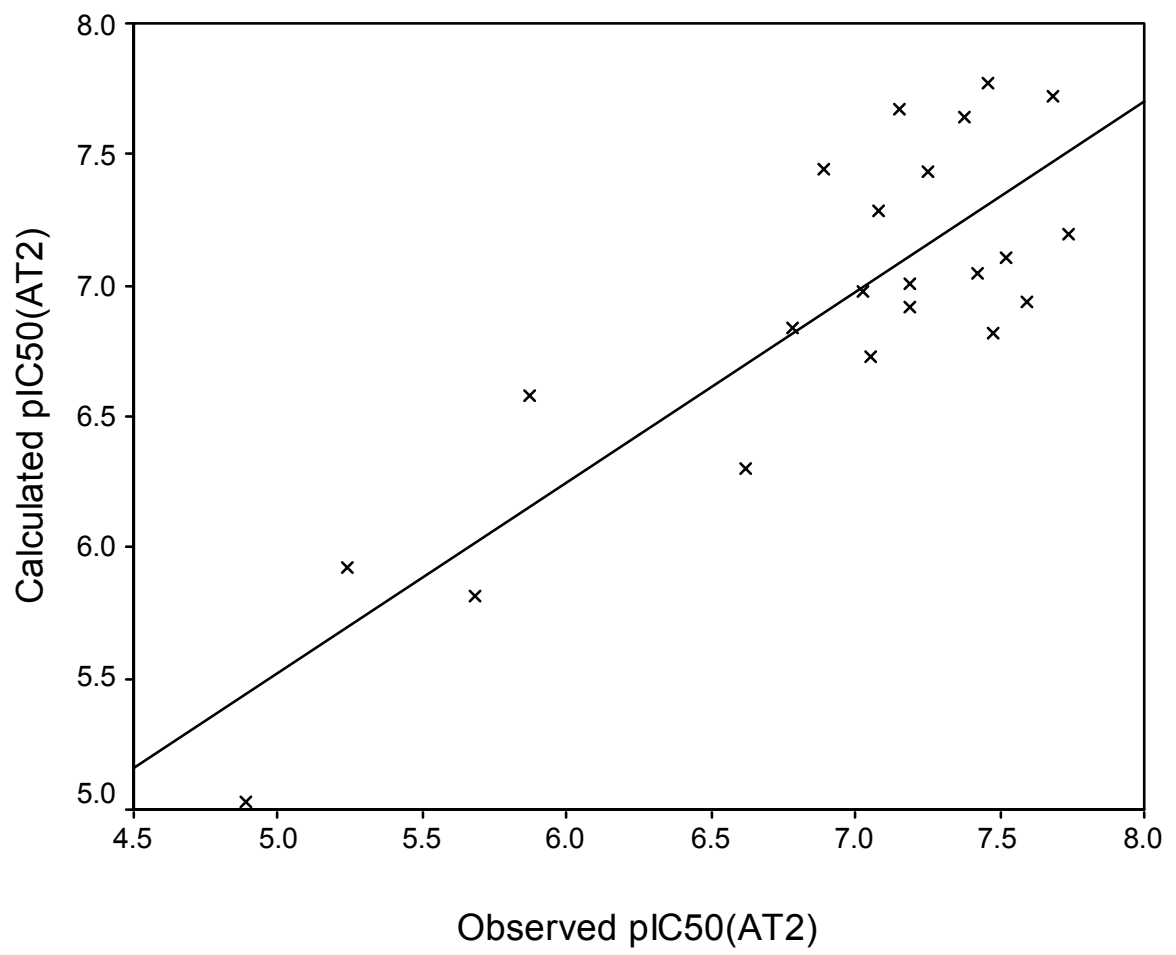

Figure 3. Plot of predicted $\mathrm{pIC}_{50}\left(\mathrm{AT}_{2}\right)$ activity values against the experimental $\mathrm{pIC}_{50}\left(\mathrm{AT}_{2}\right)$ values for the MLR model by Eq. 6 .

\section{QSAR model for $\mathrm{AT}_{2}$ antagonistic activity}

$\mathrm{pIC}_{50}\left(\mathrm{AT}_{2}\right)=-0.106( \pm 0.181) \log \mathrm{P}+7.574( \pm 1.128)$

$\mathrm{n}=22 \quad \mathrm{r}=0.130 \quad \mathrm{q}^{2}=0.0 \quad \mathrm{~F}=0.347 \quad \mathrm{~s}=0.804$

However, when we attempted non-linear regression, as in the case of $\mathrm{AT}_{1}$ antagonistic activity, the non-linear model showed an excellent correlation with $\log \mathrm{P}$. The r-value for $\log \mathrm{P}$ was increased from 0.130 to 0.782 (Eq. 8). This indicated the importance of $\log \mathrm{P}$ in contribution to the $\mathrm{AT}_{2}$ antagonistic activity.

QSAR model for $\mathbf{A T}_{2}$ antagonistic activity

$$
\begin{aligned}
& \mathrm{pIC}_{50}\left(\mathrm{AT}_{2}\right)=6.601( \pm 1.246) \log \mathrm{P}-0.524( \pm 0.097) \log \mathrm{P}^{2}-13.370( \pm 3.943) \\
& \mathrm{n}=22 \quad \mathrm{r}=0.782 \quad \mathrm{q}^{2}=0.571 \quad \mathrm{~F}=15.02 \quad \mathrm{~s}=0.518
\end{aligned}
$$




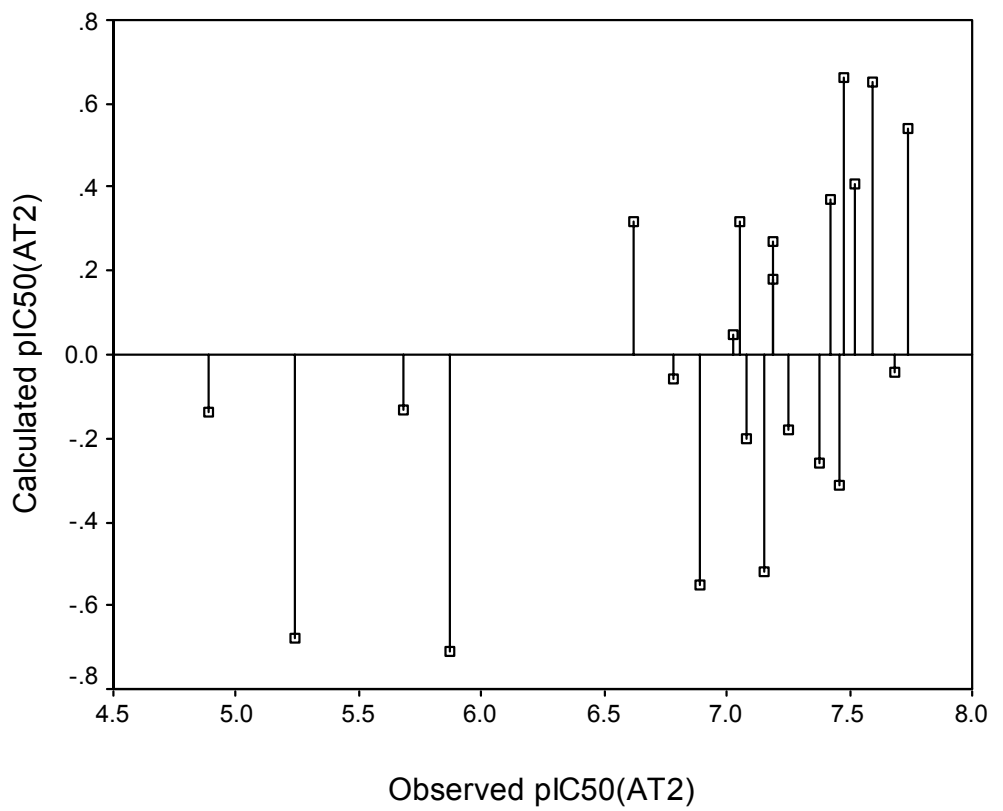

Figure 4. Plot of residuals against the experimental $\mathrm{pIC}_{50}$ values for the MLR developed model by Eq. 6 .

The non-linear model indicated that $\log \mathrm{P}$ significantly contributes to ang II antagonistic activity. Significant equations were obtained by MLR as well as NLR methods for 4,5-dihydro4-oxo-3 $\mathrm{H}$-imidazo[4,5-c]pyridines according to their angiotensin II receptor antagonistic activity. From the MLR and NLR models discussed above we conclude that the quantum chemical descriptor, energy of lowest unoccupied molecular orbital (LUMO) and the lipophilic parameter, $\log$ P, can be used successfully for modeling ang II receptor antagonistic activity. The models obtained showed not only statistical significance but also predictive ability. The present study suggests that neglecting of $\log$ P based on its low correlation by MLR as followed by most of the QSAR studies can lead to fortuitous results and one must perform non-linear regression before coming to a decision on the contribution of the lipophilic parameter, $\log \mathrm{P}$.

\section{Experimental Section}

\section{Angiotensin II receptor antagonistic activity}

The angiotensin receptor antagonistic activity was taken from the reported work of Mederski et $\mathrm{al}^{26}$ We have converted the biological activity values $\left[\mathrm{IC}_{50}(\mathrm{nM})\right]$ reported in the literature to molar units [mol/l] and then further to - log scale and subsequently used as the response variable for the QSAR analysis.

\section{Calculation of molecular descriptors and regression}

The calculation of molecular descriptors of substituted 4,5-dihydro-4-oxo-3H-imidazo[4,5c]pyridines as well as the regression analyses were carried out using the molecular package 
TSAR 3D version 3.3 for Windows. ${ }^{28}$ The details of the descriptors are available in the literature $^{29-41}$ and therefore they are not described here.

\section{Cross-validation}

The models were cross-validated by the 'leave one out' scheme ${ }^{44}$ where a model is built with N1 compounds and the $\mathrm{N}^{\text {th }}$ compound is predicted. Each compound is left out of the model derivation and predicted in turn. An indication of the performance of the model is obtained from the cross-validated (or predictive $\mathrm{q}^{2}$ ) method which is defined as

$\mathrm{q}^{2}=($ SD-PRESS/SD)

where SD is the sum of squares deviation for each activity from the mean. PRESS (or predictive sum-of -squares) is the sum of the squared difference between the actual and that of the predicted values when the compound is omitted from the fitting process. The model with high $\mathrm{q}^{2}$ value is said to have high predictability.

Further, the selected models were validated by the calculation of the following statistical parameters $^{45-46}$ : probable error of the coefficient of correlation (PE), least square error (LSE), Friedman's lack of fit measure (LOF), standard error of prediction (SEP). These parameters were calculated from the following equations:

$$
\mathrm{PE}=2\left(1-\mathrm{r}^{2}\right) / 3 \sqrt{ } \mathrm{n}
$$

where, $\mathrm{r}=$ correlation coefficient and $\mathrm{n}=$ number of compounds used.

$$
\mathrm{LSE}=\sum\left(\mathrm{Y}_{\mathrm{obs}}-\mathrm{Y}_{\mathrm{calc}}\right)^{2}
$$

where, $\mathrm{Y}_{\mathrm{obs}}$ and $\mathrm{Y}_{\text {calc }}$ are the observed and calculated values.

$$
\mathrm{LOF}=\mathrm{LSE} /\{1-(\mathrm{C}+d \cdot p / \mathrm{n})\}^{2}
$$

where, $\mathrm{LSE}=$ least square error, $\mathrm{C}=$ number of descriptors $+1, p=$ number of independent parameters, $\mathrm{n}=$ number of compounds used, $d=$ smoothing parameter which controls the bias in the scoring factor between equations with different number of terms and was kept 1.0.

$$
\mathrm{SEP}=\sqrt{\mathrm{LSE}} / \mathrm{n}
$$

The lowest values observed for the above calculated statistical parameters were used as criteria for qualifying a MLR model to be the best one among the different statistically significant MLR models developed.

\section{References and Footnotes}

1. Sealey, J. E.; Laragh, J. H. The Rennin-Angiotensin-Aldosterone System for Normal Regulation of Blood Pressure and Sodium and Potassium Homeostasis. In Hypertension: Pathophysiology, Diagnosis And Management, Berner, J. H.; Laragh, B. M., Eds., Raven Press: New York, 1990; pp 1287.

2. Blankey, C. J.; Hodges, J. C.; Klutchko, S. R.; Himmelsbach, R. J.; Chucholowski, A.; Connolly, C. J.; Neergaard, S. J.; Niewwenhze, M. S.; Sebastian, A.; Quin, J.; Essenberg, A. D.; Cohen, D. M. J. Med. Chem. 1991, 34, 3248. 
3. Dudley, D. T.; Panek, R. L.; Major, T.; Lu, G. H.; Bruns, R. F.; Klinkefus, B. A.; Hodges, J. C.; Weishaar, R. E. Mol. Pharmacol. 1990, 80, 370.

4. Whitebread, S.; Mele, M.; Kamber, B.; de Gasparo, M. Biochem. Biophys. Res. Commun. 1989, 163, 284.

5. Chiu, A. T.; Herblin, W. F.; McCall, D. E.; Ardecky, R. J.; Carini, D. J.; Duncia, J. V.; Pease, L. J.; Wong, P. C.; Wexier, R. R.; Johnson, A. L.; Timmermanns, P. B. M. W. M. Biochem. Biophys. Res. Commun. 1989, 165, 196.

6. Timmermanns, P. B. M. W. M.; Wong, P. C.; Chiu, A. T.; Herblin, W. F.; Benfield, P.; Carini, D. J.; Lee, R. J.; Wexler, R. R.; Saye, J. A. M.; Smith, R. D. Pharmacol. Rev. 1993, $45,205$.

7. Catt, K. J.; Sandberg, K.; Balla, T. Angiotensin II Receptors and Signal Transduction Mechanisms. In Cellular And Molecular Biology of the Renin Angiotensin System, Eds., Raizada, M. K.; Philips, M. I.; Sumners, C. CRC Press Inc.: Boca Raton, FL, 1993; pp 307.

8. Mukoyama, M.; Nakaijima, M.; Horiuchi, M.; Sasamura, H.; Pratt, R. E.; Dzau, V. J. J. Biol. Chem. 1993, 268, 24539.

9. Kambayashi, Y.; Bardhan, S.; Takahashi, K.; Tsuzuki, S.; Inui, H.; Hamakubo, T.; Inagami, T. J. Biol. Chem. 1993, 26, 24543.

10. Bottari, S. P.; King, I. N.; Reichlin, S.; Dahlstroem, I.; Lyndon, N.; de Gasparo, M. Biochem. Biophys. Res. Commun. 1993, 183, 206.

11. Bottari, S. P.; de Gasparo, M.; Stockelings, U. M.; Levens, N. R. Front. Neuroendocrinol. 1993, 14, 132.

12. Keiser, J. A.; Olszewski, B.; Hicks, G.; Ryan, M. J.; Hodges, J. FASEB J. 1993, 7, A654.

13. Kubo, K.; Kohara, Y.; Imamiya, E.; Sigiura, Y.; Inada, Y.; Furukawa, Y.; Nishikawa, K.; Naka, T. J. Med. Chem. 1993, 36, 2182.

14. Nicolai, E.; Cure, G.; Goyard, J.; Kirchner, M.; Teulon, J. M.; Versigny, A.; Cazes, M.; Virone-Oddos, A.; Caussade, F.; Cloarec, A. Eur. J. Med. Chem. 1995, 30, 365.

15. Whitesitt, C. A.; Steinberg, M. I.; Zimmerman, K. M.; Wiest, S. A.; Lifer, S. L.; Reel, J. K.; Simon, R. L. FASEB J. 1992, 5, 5412.

16. Allen, E. E.; de Laszlo, S. E.; Huang, S. X.; Quagliato, C. S.; Greenlee, W. J.; Chang, R. S.; Chen, T. B.; Faust, K. A.; Lotti, V. J. Bioorg. Med. Chem. Lett. 1993, 3, 1293.

17. Gupta, S. P.; Mathur, A. N.; Nagappa, A. N.; Kumar, D.; Kumaran, S. Eur. J. Med. Chem. 2003, 38, 867.

18. Narasimhan, B.; Kothawade, U. R.; Pharande, D. S.; Mourya, V. K.; Dhake, A. S. Indian J. Chem., 2003, 42B, 2828.

19. Narasimhan, B.; Belsare, D.; Pharande, P.; Mourya, V.; Dhake, A. Eur. J. Med. Chem., 2004, 39, 827.

20. Narasimhan, B.; Mourya, V.; Dhake, A. Biorg. Med. Chem. Lett. 2006, 16, 3023.

21. Narasimhan, B.; Mourya, V. K.; Dhake, A. S. Khim.-Farm. Zh., 2007, 3, 120.

22. Narasimhan, B.; Kumari, M.; Jain, N.; Dhake, A.; Sundaravelan, C. Biorg. Med. Chem. Lett. 2006, 16, 4951 . 
23. Gangwal, N. A.; Narasimhan, B.; Mourya, V. K.; Dhake, A. S. Indian J. Het. Chem., 2003, 12, 201.

24. Narasimhan, B.; Kumari, M.; Dhake, A.; Sundaravelan, C. ARKIVOC, 2006, xiii, 73.

25. Narasimhan, B.; Ansari, M. A.; Singh, N.; Mourya, V.K .; Dhake, A. S. Chem. Pharm. Bull. 2006, 54, 1067.

26. Mederski, W. W. K. R.; Dorsch, D.; Osswald, M.; Schwatz, H.; Beier, N.; Christadler, M.; Minck, K. O.; Schelling, P.; Schmitges, C. J. Eur. J. Med. Chem. 1997, 32, 479.

27. Furusjo, E.; Svenson, A.; Rahmberg, M.; Andersson, M. Chemosphere 2006, 63, 99.

28. TSAR 3D, Version 3.3, Oxford Molecular Limited, 2000.

29. Kubinyi, H. In QSAR-Hansch Analysis and Related Approaches; Vol-1; VCH Publishers: New York; 1993: pp 1.

30. Hansch, C. In Comprehensive Medicinal Chemistry; Vol. 4; $1^{\text {st }}$ Ed.; Pergamon Press: Oxford, 1990; pp 9.

31. Wiener, H. J. Am. Chem. Soc. 1947, 69, 17.

32. Randic, M. J. Am. Chem. Soc. 1975, 97, 6609.

33. Kier, L. B.; Hall, L. H. In Molecular Connectivity in Structure-Activity Analysis; Research Studies Press: Letchworth, 1986; pp 20.

34. Zefirov, N. S.: Kirpichenok, M. A.; Izmallov, F. F.; Trofirnov, M. I. Dokl. Akad. Nauk SSSR 1987, 296, 883.

35. Kirpichenok, M. A.; Zefirov, N. S. Zh. Org. Khim. 1987, 23, 673.

36. Stanton, D. T.; Jurs, P. C. Anal. Chem. 1990, 62, 2323.

37. Stanton, D. T.; Egolf, L. M.; Jurs, P. C.; Hicks, M. G. J. Chem. Inf Comput. Sci. 1992, 32 , 306.

38. Rohrbaugh, R. H.; Jurs, P. C. Anal. Chim. Acta 1987, 199, 99.

39. Karelson, M. In Molecular Descriptors in QSAR/QSPR; John Wiley \& Sons: New York, 2000; pp 100.

40. Karelson, M.; Lobanov, V. S.; Katritzky, A. R. Chem. Rev. 1996, 96, 1027.

41. Breneman, C. M.; Martinov, M. In Molecular Electrostatic Potentials: Concepts and Applications, Theoretical and Computational Chemistry; Vol. 3; Eds. Murray, J. S.; Sen, K., Eds., Elsevier Science: Amsterdam, 1996; pp 54.

42. Monasterios, M.; Escorche, M.; Avendano, M. J. Mol. Struct. 2005, 748, 49.

43. Monasterios, M.; Avendano, M.; Amaro, M. I.; Infante, W.; Charris, J. J. Mol. Struct. 2006, $798,102$.

44. Agarwal, V. K.; Singh, J.; Mishra, K. C.; Khadikar, P. V.; Jaliwala, Y. A. Arkivoc 2006, (ii), 162.

45. Mandloi, D.; Joshi, S.; Khadikar, P. V.; Khosla, N. Bioorg. Med. Chem. Lett. 2005, 15, 405.

46. Pinheiro, A. A. C.; Borges, R. S.; Santos, L. S.; Alves, C. N. J. Mol. Struct. (Theochem). 2004, 672, 215. 